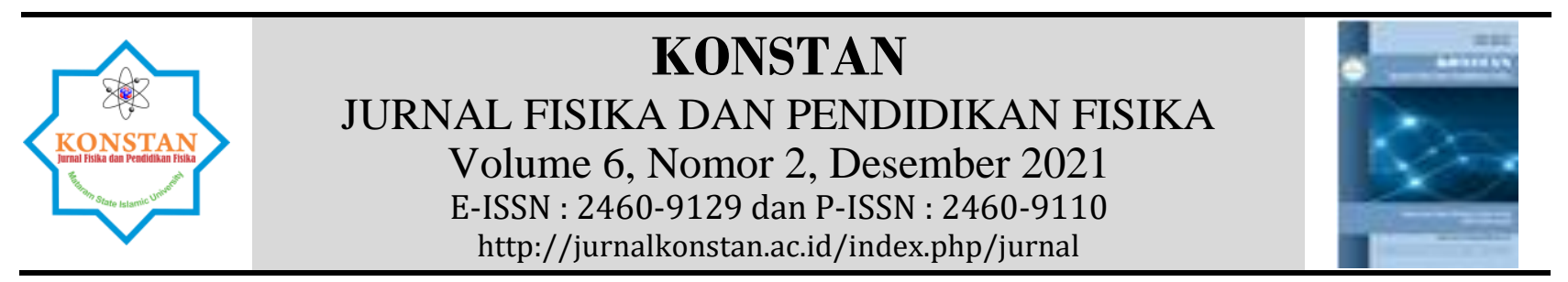

\title{
Pembelajaran Fisika Mengintegrasikan Etnosains Permainan Tradisional
}

\author{
Azmi Asra $^{1, *)}$, Festiyed $^{2}$, Fatni Mufit ${ }^{2}$, Asrizal $^{2}$ \\ 1) Universitas Pasir Pengaraian,Riau, Indonesia \\ 2) Universitas Negeri Padang,Sumatera Barat, Indonesia \\ *E-mail korespondensi: zulhamasra@gmail.com
}

\begin{abstract}
Info Artikel: Abstrak
Dikirim:

26 Februari 2021

Revisi:

08 Sept 2021

Diterima:

31 Desember 2021

Narrative Literature Review ini bertujuan untuk mengetahui pembelajaran fisika mengintegrasikan etnosains permainan tradisional. Narrative Literature Review ini menelusuri jurnal penelitian dalam masalah sejenis, diambil secara purposive berdasarkan kesesuaian dengan topik. Jurnal yang digunakan berasal dari basis data beberapa publisher baik nasional dan juga internasional sebanyak 38 jurnal dalam kisaran lima tahun terakhir (2020-2015). Analisis data menggunakan deskriptif kualitatif. Hasil dari Narrative Literature Review ini menunjukan bahwa pembelajaran

\section{Kata Kunci:}

Pembelajaran

Fisika, Etnosains,

Permainan

Tradisional fisika mengintegrasikan etnosains permainan tradisional telah dilakukan peneliti dalam bentuk konsep dan prinsip fisika, pembelajaran fisika sangat erat kaitannya dengan kehidupan nyata sehari-hari, pengintegrasian etnosains dalam pembelajaran fisika sangat penting dilakukan serta memberikan dampak yang signifikan dalam upaya meningkatkan hasil dan motivasi belajar peserta didik serta kearifan lokal dalam bentuk permainan sangat cepat dan familiar pada peserta didik, dengan bermain seperti permainan tradisional membuat peserta didik dengan rasa senang dapat mengikuti dan melakukannya, peserta didik memiliki keterampilan berpikir logis dan kritis dengan melihat peserta didik yang lain saat interaksi dalam bermain.
\end{abstract}

\begin{abstract}
This Narrative Literature Review aims to determine physics learning integrating the ethnoscience of traditional games. This Narrative Literature Review explores research journals on similar issues, taken purposively based on their suitability to the topic. The journals used come from a database of several publishers both national and international as many as 38 journals in the last five years (2020-2015). Data analysis using descriptive qualitative. The results of this Narrative Literature Review show that physics learning integrating traditional game ethnoscience has been carried out by researchers in the form of concepts and principles of physics, physics learning is very closely related to everyday real life, integrating ethnoscience in learning physics is very important and has a significant impact on efforts to improve learning outcomes and motivation of students as well as local wisdom in the form of a game that is very fast and familiar to students, by playing like traditional games, students can happily follow and do so, students have logical and critical thinking skills by looking at students the other during interaction in play.
\end{abstract}

(C) 2021 Universitas Islam Negeri Mataram

\section{PENDAHULUAN}

Peraturan Pemerintah Nomor 17 Tahun 2010 Pasal 34, menyebutkan bahwa pendidikan berbasis keunggulan lokal adalah pendidikan yang diselenggarakan setelah memenuhi standar 
nasional pendidikan dan diperkaya dengan keunggulan kompetitif dan/atau komparatif daerah. Menurut Peraturan Pemerintah Nomor 17 Tahun 2010 Pasal 35 Ayat 2, Pemerintah kabupaten/kota melaksanakan dan/atau memfasilitasi perintisan program dan/atau satuan pendidikan yang sudah atau hampir memenuhi standar nasional pendidikan untuk dikembangkan menjadi program dan/atau satuan pendidikan bertaraf internasional dan/atau berbasis keunggulan lokal.

Indonesia merupakan negara yang kaya akan keunggulan lokal dengan keanekaragaman isinya, memiliki provinsi sebanyak 34, kabupaten 416 dan kota 98, kemudian terbagi lagi ke dalam beragam suku bangsa menjadikan Indonesia kaya akan kebudayaan-kebudayaan yang unik [1]. Kekayaan budaya inilah yang kemudian menjadi identitas tersendiri bagi suatu suku bangsa dan menunjukkan jati dirinya. Di Indonesia sendiri kekayaan budaya tersebut meliputi rumah-rumah adat, lagu daerah, tari tradisional, pakaian tradisional, makanan tradisional, situs bersejarah, adat istiadat, permainan tradisional dan lain sebagainya [2], kekayaan yang beranekaragam ini dikenal dengan kearifan lokal.

Selain menjadi bagian budaya bangsa, kearifan lokal menjadi salah satu kekayaan dan kebanggaan bangsa Indonesia yang harus dilestarikan. Menjadi pemersatu bangsa dalam bingkai Bhinnneka Tunggal Ika, berbeda-beda tapi tetap satu. Kearifan lokal tersebut menjadi pedoman hidup dan dijalankan oleh masyarakat karena dipercaya sebagai suatu hal yang baik dan penuh kebijaksanaan[3]. Selain itu, Novitasari, Agustina, Sukesti, Nazri dan Hadhika menyatakan bahwa kearifan lokal merupakan wujud pemahaman masyarakat terhadap alam dan budayanya. Kearifan lokal juga merupakan cerminan dari etnosains yang dimiliki oleh suatu komunitas budaya tertentu, satu diantaranya seperti permainan tradisional[4].

Permainan tradisional yang terdapat di Indonesia merupakan permainan yang berasal dari tradisi dan kebudayaan di setiap daerah[5]. Dalam pelaksanaannya, permainan tradisional memanfaatkan lingkungan sebagai sarana untuk bermain, selain itu dalam memainkannya tidak secara individu melainkan dalam kelompok yang terdiri dari banyak orang. Permainan tradisional tidak hanya sebagai wahana bermain anak, namun juga sebagai sarana pengembangan karakter karena terdapat nilai-nilai yang terkandung didalamnya. Sujarno menuliskan bahwa nilai-nilai yang terkandung dalam permainan tradisional meliputi nilai sportivitas, nilai gotong royong, nilai pendidikan, nilai moral, nilai demokrasi dan nilai keberanian[6]. Nilai-nilai budaya tersebut memiliki efek positif membangun kepribadian anak untuk menjadi penerus bangsa yang berbudi luhur[7]. Nilai-nilai ini memiliki peran yang besar dalam membentuk dan menjaga keutuhan bangsa Indonesia.

Akan tetapi di era global saat ini, kedudukan permainan tradisional pada generasi muda termasuk peserta didik yang ada di sekolah mulai tergeser akibat eksistensi teknologi yang kemudian mengembangkan permainan menjadi bersifat modern. Permainan modern sendiri menyajikan bentuk permainan yang efektif dan efisien serta dalam pelaksanaannya tidak membutuhkan tempat yang luas beda halnya dengan permainan tradisional[8]. Peserta didik tidak lagi mengenal dan mengetahui beberapa istilah permainan tradisional yang dahulunya sering dimainkan seperti bobodie, dobong, gasing, adu buah para dan lain sebagainya.

Tersisihnya permainan tradisional juga tidak dapat dipungkiri, hal ini diakibatkan oleh perkembangan teknologi yang terus berkembang pesat dan berdampak pada berbagai aspek, termasuk permainan anak. Purwaningsih menyebutkan bahwa jumlah permainan tradisional anak berjumlah 60, dalam sumber lain menyebutkan bahwa jumlah permainan tradisonal anak di Indonesia berjumlah 241. Semua permainan tradisional ini kaya akan kandungan nilai-nilai pendidikan dan pembelajaran termasuk pembelajaran sains fisika[7].

Dalam permainan tradisional ada juga beberapa permainan berkaitan erat dengan konsep pembelajaran fisika salah satunya gasing dan perahu pelepah pisang yang berkaitan dengan konsep fisika yaitu pada konsep rotasi dan tekanan[9]. Pada permainan tradisional Kalimantan Tengah yang dimiliki suku Dayak Ngaju yaitu permainan Balogo dan Habayang, permainan ini mengandung materi fisika momentum dan impuls[10]. Hal yang sama pada permainan tarik tambang adalah permainan tradisional yang mengandung beberapa materi fisika diantaranya materi usaha dan energi, momentum dan impuls, kinematika, dinamika, kesetimbangan benda tegar dan lain-lain[11].

Kenyataan bahwa pemahaman konsep fisika siswa di sekolah masih rendah. Saat ini yang terjadi di kalangan anak muda lebih tertarik pada permainan modern berupa playstastion dan game 
online yang ada pada gadget mereka dan permainan tradisional sudah mulai ditinggalkan[12]. Hal ini tentunya bertentangan dengan semangat yang terkandung dalam PP No. 17 Tahun 2010 yang ingin mewujudkan pendidikan berbasis keunggulan lokal.

Oleh karena itu, pembahasan ini sangat menarik dan penting dalam pembelajaran fisika dengan mengintegrasikan etnosains permainan tradisional. Tanpa menyampingkan faktor lain, bermain merupakan salah satu faktor yang lebih cepat dan familiar peserta didik menerima dan mengikutinya, hal ini sesuai pula pembelajaran fisika yang erat kaitannya dengan kehidupan nyata dan dengan sendirinya poin kandungan pembelajaran fisika yang dimaksud akan dapat tersampaikan kepada peserta didik. Hal ini selaras dengan Asrizal, Festiyed dan Ramdhan yang menjelaskan bahwa materi pembelajaran IPA mesti dikaitkan dengan situasi dunia nyata. Dengan cara ini, pembelajaran IPA terpadu mampu mendukung kerangka pengembangan kurikulum IPA di $\mathrm{SMP} / \mathrm{MTs}[13]$.

Agar eksistensi keunggulan lokal dan kearifan lokal berupa permainan tradisional tetap kukuh, maka peserta didik sebagai generasi penerus perlu ditanamkan rasa peduli dan cinta terhadap kebudayaan dan kearifan lokal dengan cara mengangkat kembali pengetahuan peserta didik terhadap permainan tradisional serta mengintegrasikan pengetahuan budaya dalam proses pembelajaran khususnya pembelajaran fisika. Untuk itu, diperlukan suatu inovasi pendidikan yang menggabungkan antara budaya dengan sains atau biasa disebut dengan etnosains[14].

Kajian Narrative Literature Review ini bertujuan diantaranya, pertama untuk mengidentifikasi konsep-konsep fisika yang terdapat pada permainan tradisional yang ditemukan oleh para peneliti, kedua untuk mengetahui kompetensi siswa yang dapat ditingkatkan melalui pengintegrasian permainan tradisional dalam pembelajaran fisika, serta yang ketiga untuk mengetahui topik-topik etnosains fisika yang terdapat pada kebudayaan masyarakat khususnya permainan tradisional.

\section{METODE PENELITIAN}

Penelitian ini menggunakan metode Narrative Literature Review. Narrative Literature Review merupakan review paper yang bertujuan untuk mengindentifikasi beberap studi yang menggambarkan suatu topik tertentu, format ini tida ada acuan sistematis baku, tetapi minimal memuat informasi kritis tentang hasil penelitian pada paper. Reviewer membaca keseluruhan isi paper dan membuat tabulasi dari informasi kritis pada paper dalam satu topik[15]. Topik Narrative Literature Review ini mengenai pembelajaran fisika mengintegrasikan etnosains permainan tradisional. Instrumen dalam penelitian ini menggunakan human instrument yakni peneliti sendiri yang bertindak sebagai instrumen penelitian. Populasi penelitian ini adalah jurnal dan paper yang diperoleh secara online dari data base publisher nasional dan internasional mengenai pembelajaran fisika mengintegrasikan etnosains permainan tradisional kisaran lima tahun terakhir (2020-2015). Sampel penelitian menggunakan teknik purposive sampling dikarenakan sampel yang diambil sesuai dengan tema penelitian. Analisis data yang digunakan dalam penelitian ini adalah analisis data kualitatif untuk data-data hasil kajian naratif terhadap penelitian-penelitian yang ditemui.

Langkah-langkah Narrative Literature Review bisa dilihat pada gambar 1 berikut.

\begin{tabular}{|c|c|}
\hline $\begin{array}{l}\text { 1. Lakukan Pencarian Jurnal } \\
\text { /Paper Sesuai Topik }\end{array}$ & $\begin{array}{l}\text { 2. Tentukan Kata Kunci/ keyword } \\
\text { Pencarian }\end{array}$ \\
\hline (2) & \\
\hline $\begin{array}{l}\text { 3. Fokus Review Abstrak } \\
\text { Kemudian Isi Jurnal/Paper }\end{array}$ & $\begin{array}{l}\text { 4. Membuat Ringkasan/Sintesis } \\
\text { Dokumen Hasil Review }\end{array}$ \\
\hline
\end{tabular}

Gambar 1. Langkah-langkah Narrative Literature Review

Sumber: Behavioral Intervention Research in Hospice and Palliative Care - Building an Evidence Base. ScienceDirect.Com

\section{HASIL DAN PEMBAHASAN}

Narrative literature review ini membahas tentang pembelajaran fisika mengintegrasikan etnosains permainan tradisional meliputi langkah-langkah berikut: 
1. Pencarian Paper

Penulis melakukan pencarian paper atau literature ilmiah yang diterbitkan dalam berbagai database untuk memastikan bahwa mayoritas studi yang relevan teridenfikasi sesuai dengan topik yang telah ditentukan.

Tabel 1. Hasil penelusuran jurnal dan paper yang relevan

\begin{tabular}{lcc}
\multicolumn{1}{c}{ Jurnal/Paper } & \multicolumn{2}{c}{ Jumlah } \\
\cline { 2 - 3 } & \multicolumn{2}{c}{ Total } \\
\hline Etnosains dalam pembelajaran & 38 & \\
Pembelajaran lebih luas & & 21 \\
Lingkungan & & 4 \\
Permainan tradisional & & 13 \\
\hline
\end{tabular}

Dari tabel 1 dapat dijelaskan bahwa hasil literature ilmiah yang dilakukan, ditemukan 38 jurnal dan paper pembelajaran etnosains, 21 jurnal dan paper yang ditelusuri memiliki kajian etnosains dengan kaitan pembelajaran lebih luas mencakup hasil belajar, kemampuan berpikir kritis, literasi sains, kemampuan kewirausahaan serta karakter peserta didik. 4 jurnal dan paper memiliki kajian etnosains dengan lingkungan seperti jiwa konservasi peserta didik, ekosistem, polusi dan peduli lingkungan. Kemudian 13 jurnal dan paper memiliki kajian etnosains dengan permainan tradisional seperti gasing, egrang, ketapel, kasti, mallogo serta tarik tambang.

2. Menentukan kata kunci atau keyword

Dari 38 jurnal dan paper yang ditemukan dan dikumpulkan, penulis melanjutkan dengan melakukan penyortian sesuai dengan topik yang sesuai dengan topik bahasan narrative literature review ini.

Berdasarkan topik bahasan yang ditentukan yakni pembelajaran fisika mengintegrasikan etnosains permainan tradisional, ditemukan 13 jurnal dan paper yang memiliki relevansi dengan narrative literature review ini seperti konsep dan prinsip Fisika pada permainan tradisional, gerak parabola pada permainan tradisioanal serta modul berbasis kearifan lokal permainan tradisional pada materi momentum dan impuls.

3. Fokus review abstrak dan isi paper

Setelah pencarian selesai dan jurnal/paper telah disortir, maka abstrak dari artikel yang dipilih untuk memastikan bahwa jurnal/paper sesuai dengan topik bahasan narrative literature review dengan ulasan naratif, meliputi informasi kritis pada hasil riset jurnal dan paper tersebut. Dapat dilihat pada tabel 2 berikut.

Tabel 2. Hasil narasi literatur review

\begin{tabular}{|c|c|c|c|}
\hline $\begin{array}{c}\text { Nama } \\
\text { Penulis }\end{array}$ & Objek & $\begin{array}{c}\text { Permainan } \\
\text { Tradisional } \\
\end{array}$ & Hasil \\
\hline $\begin{array}{l}\text { Ketang } \\
\text { Wiyono, } \\
\text { Ismet, } \\
\text { Murniati, Sri } \\
\text { Zakiyah, } 2017\end{array}$ & $\begin{array}{l}\text { Konsep dan } \\
\text { Prinsip } \\
\text { Fisika }\end{array}$ & $\begin{array}{lr}\text { Gasing, } & \text { Egrang, } \\
\text { Paraga, ngadu } \\
\text { muncang, boi-boian, } \\
\text { kelereng, bola bekel, } \\
\text { meriam bamboo, } \\
\text { malogo, gatrik, } \\
\text { bakiak, kelereng, } \\
\text { kasti, ketapel, laying- } \\
\text { layang, lenggang } \\
\text { rotan, tarik tambang }\end{array}$ & $\begin{array}{l}\text { Pada permainan tradisional terdapat } \\
\text { konsep fisika dengan dominasi pada materi } \\
\text { dinamika dan kinematika. Pada } \\
\text { Kompetensi Dasar (KD) ranah } \\
\text { pengetahuan yang terdapat pada konten } \\
\text { fisika dalam permainan tradisional untuk } \\
\text { kelas X didominasi KD } 3.7 \text { dan KD 3.9, } \\
\text { sedangkan untuk kelas XI, dominasi materi } \\
\text { berada pada KD } 3.1 \text { yang membahas } \\
\text { materi tentang momentum, titik berat, dan } \\
\text { kesetimbangan benda tegar[16]. }\end{array}$ \\
\hline $\begin{array}{l}\text { Widyaparamit } \\
\text { a, Sahrul } \\
\text { Saehana, dan } \\
\text { I } \quad \text { Wayan }\end{array}$ & $\begin{array}{l}\text { Hasil Belajar } \\
\text { Fisika Siswa }\end{array}$ & $\begin{array}{l}\text { Permainan } \\
\text { dan perahu }\end{array}$ & $\begin{array}{l}\text { Hasil belajar kelompok siswa yang } \\
\text { mendapatkan perlakuan dengan media } \\
\text { permainan gasing dan permainan perahu } \\
\text { pada taraf nyata berbeda secara signifikan }\end{array}$ \\
\hline Darmadi, & & & dengan kelompok siswa yang tidak \\
\hline
\end{tabular}


2020

\begin{tabular}{lll} 
Ilza Ma'azi & Motivasi dan & Kasti \\
Azizah, & Hasil Belajar & \\
$2016 \quad$ & Materi Gaya & \\
Nur Laily & Modul Fisika & Permainan \\
Makhmudah, & Materi & Tradisional \\
Subiki, & Momentum & Kalimantan Tengah \\
Supeno, & dan Impuls & \\
\hline
\end{tabular}

2019

Noly

Shofiyah, Ria Partikel

Wulandari,

Enik

Setiyawati,

2020

$\begin{array}{ll}\text { Aprilaras } & \text { Modul } \\ \text { Dewi Pratiwi, } & \text { Pembela } \\ 2019 & \text { jaran } \\ \text { Ferina } & \text { Nilai } \\ \text { Agustini, } & \text { Karakter } \\ 2020 & \end{array}$

Alifah Hasil Belajar Permaian Engklek Kusumanings Siswa ih, 2019
Bobodie dan Egrang

Tarik Tambang

Tarik tambang dan geredan pelepah pinang

menggunakan permainan[9].

Motivasi belajar siswa secara efektif meningkat dengan menerapkan permainan tradisional[17]

Peningkatan hasil belajar siswa materi impuls dan momentum setelah diterapkan modul pembelajaran berbasis permainan tradisional[10].

Modul Dinamika Partikel berbasis kearifan lokal permainan tradisional valid dan layak untuk diimplementasikan dalam pembelajaran jarak jauh (e-learning) serta berpengaruh terhadap keterampilan literasi sains mahasiswa[18]

Hasil dari validasi menunjukkan kategori "sangat baik" sehingga layak digunakan oleh guru.[19]

Nilai karakter yang muncul melalui permainan tradisional tarik tambang dalam pembelajaran IPA adalah kerjasama. Melalui permainan tersebut siswa mendapatkan pengalaman belajar yang bermakna berkaitan dengan materi gerak dan gaya[20]

Hasil belajar IPA siswa antara pembelajaran yang menggunakan permainan engklek dan pembelajaran konvensional, berbeda secara signifikan. Berdasarkan uji effect size menunjukan peningkatan hasil belajar siswa termasuk dalam kategori tinggi sehingga penerapan permainan tradisional engklek efektif untuk meningkatkan hasil belajar siswa[21].

\begin{tabular}{|c|c|c|c|}
\hline $\begin{array}{l}\text { Hasbullahair } \\
\text { Ashar, } \\
2017\end{array}$ & $\begin{array}{l}\text { Hasil Belajar } \\
\text { Fisika }\end{array}$ & Permaian Engklek & $\begin{array}{l}\text { Terdapat pengaruh hasil belajar fisika yang } \\
\text { diajar menggunakan pembelajaran diskusi } \\
\text { caologium berbasis permainan engklek[22]. }\end{array}$ \\
\hline $\begin{array}{l}\text { Rizalul Fiqry, } \\
2017\end{array}$ & $\begin{array}{l}\text { Keteram } \\
\text { pilan } \\
\text { Berpikir } \\
\text { Logis }\end{array}$ & Gasing "Kawongga" & $\begin{array}{l}\text { Konsep-konsep fisika yang dapat } \\
\text { digunakan dalam penyusunan modul } \\
\text { pembelajaran Fisika dapat meningkatkan } \\
\text { keterampilan berpikir logis siswa di era } \\
\text { pembelajaran abad } 21 \text { ini[23]. }\end{array}$ \\
\hline
\end{tabular}

4. Membuat ringkasan dan sintesis dokumen hasil review paper

Dari abstrak yang direview diperoleh ringkasan bahwa pada permainan tradisional terdapat konsep-konsep dan prinsip-prinsip fisika seperti pada materi dinamika, kinematika, impuls momentum, titik berat, kesetimbangan benda tegar dan dinamika partikel (Wiyono, Ismet, Murniati dan Sri Zakiyah, 2017)[16], (Makhmudah, Subiki dan Supeno, 2019)[10] dan Shofiyah, Ria dan Enik, 2020)[18] serta gerak dan gaya (Agustini, 2020)[20]

Penggunaan permainan tradisional juga sangat memiliki dampak yang signifikan dalam meningkatkan hasil dan motivasi belajar peserta didik (Widyaparamita, Sahrul dan I Wayan, 2020)[9], (Azizah, 2016)[17], Kusumaningsih (2019)[21] dan (Ashar, 2017)[22] serta dapat juga meningkatkan 
keterampilan berpikir logis siswa di era pembelajaran abad 21 ini (Fiqry, 2017)[23] dan keterampilan sains mahasiswa (Shofiyah, Ria dan Enik, 2020)[18].

Nilai karakter juga muncul melalui permainan tradisional tarik tambang dalam pembelajaran IPA seperti kerjasama. Melalui permainan tersebut siswa mendapatkan pengalaman belajar yang bermakna berkaitan dengan materi gerak dan gaya (Agustini, 2020) [20].

Etnosains permainan tradisional dapat juga diintegrasikan dalam pembelajaran fisika dalam bentuk modul (Pratiwi, 2019)[24], (Makhmudah, Subiki dan Supeno, 2019)[10] dan e-learning (Shofiyah, Ria dan Enik, 2020)[18].

Berdasarkan tujuan dari kajian narrative literature review ini, maka dari penyortiran yang dilakukan terhadap 38 jurnal, ditemukan 13 jurnal memiliki relevansi dengan tujuan dan topik pembelajaran fisika mengintegrasikan etnosains permainan tradisional sebagai berikut:

Pembelajaran fisika memiliki hubungan yang sangat erat dengan kehidupan nyata sehari-hari, seperti masyarakat di desa yang sebagian besar ada menggunakan sumur sebagai sumber air, maka untuk mendapatkan air di dalam sumur tersebut, masyarakat menggunakan katrol atau kayu yang panjang untuk mengangkat dan mengungkit air dari dalam sumur. Penggunaan katrol dan pengungkit dalam kebiasaan sehari-hari masyarakat ini sudah mengandung beberapa konsep dalam pembelajaran fisika seperti gaya dan kesetimbangan benda tegar. Konsep ini dibahas diantaranya oleh Wiyono, Ismet, Murniati dan Sri Zakiyah (2017)[25] dan Agustini (2020)[20].

Pengintegrasian etnosains dalam pembelajaran fisika sangat penting dilakukan serta memberikan dampak yang signifikan dalam upaya meningkatkan hasil dan motivasi belajar, dalam belajar peserta didik dijelaskan bahwa dalam kebiasaan dan budaya yang mereka lakukan sehari-hari mengandung banyak konsep dan prinsip pembelajaran fisika, hal ini juga berdampak sebaliknya bahwa dengan mengintegrasikan kebudayaan dan kebiasaan peserta didik, dapat memperkokoh, melestarikan dan mengangkat kembali kearifan lokal daerahnya menjadi pembelajaran fisika dengan berbasis keunggulan lokal sesuai dengan amanat yang dipesankan dalam PP No. 17 Tahun 2010 pasal 34 dan 35.

Kearifan lokal yang sangat cepat dan familiar diterapkan dalam pembelajaran peserta didik diantaranya dalam bentuk permainan, dengan bermain seperti permainan tradisional membuat peserta didik dengan rasa senang dapat mengikuti dan melakukannya, peserta didik memiliki keterampilan berpikir logis dan kritis dengan melihat peserta didik yang lain saat interaksi dalam bermain. Permainan tradisional yang dapat diterapkan dalam pembelajaran fisika seperti pada tabel 3 berikut.

Tabel 3. Permainan Tradisional dan Konsep Pembelajaran Fisika

\begin{tabular}{|c|c|}
\hline $\begin{array}{l}\text { Permainan } \\
\text { Tradisional }\end{array}$ & Hasil \\
\hline Gasing & $\begin{array}{l}\text { Hukum Newton I dan II, Gerak Melingkar, Torsi dan Mementum sudut, } \\
\text { Gaya Gesek dan Tekanan }\end{array}$ \\
\hline Egrang & Keseimbangan, Gaya Berat, Gaya Gravitasi \\
\hline Paraga & Gerak, Gerak Parabola, Gaya Gravitasi, Keseimbangan \\
\hline Ngadu muncang & Gaya dan Tekanan \\
\hline Boi-boian & Usaha, Perubahan arah gerak benda, Kecepatan \\
\hline Kelereng & Gerak, Tumbukan Momentum dan impuls. Hukum Newton \\
\hline Bola bekel & Momentum dan impuls, Energi Kinetik, Energi Potensial, \\
\hline $\begin{array}{l}\text { Meriam } \\
\text { bamboo/Dobong }\end{array}$ & Tekanan, Impuls dan Momentum, Gerak Parabola, Intensitas Bunyi \\
\hline Malogo & Gaya Gesek, Momentum (tumbukan), Vektor \\
\hline Gatrik & Hukum Newton I, II dan III \\
\hline Bakiak & Kesimbangan benda tegar \\
\hline Perahu Air & $\begin{array}{l}\text { Tekanan, Tekanan Uap Air, Sifat Benda Cair, Hukum Arcimedes, } \\
\text { Tekanan Hidrostatis }\end{array}$ \\
\hline Kasti & Gaya, Gerak Lurus, Gerak Parabola \\
\hline Ketapel & Energi gaya pegas, energi potensial dan gerak lurus, Elastisitas \\
\hline
\end{tabular}


Layang-layang

Lenggang rotan

Tarik tambang

Bodie
Tarikan, Gaya angkat aerodinamis, Gaya berat atau Gravitasi dan Gaya dorong

Gerak Melingkar

Hukum Newton I, II dan III

Tekanan, Impuls dan Momentum, Gerak Parabola

Pada permainan tradisional-permaianan tradisional yang didapat para peneliti dapat dikaitkan dengan konsep pembelajaran fisika mencakup materi Hukum Newton I dan II, Gerak Melingkar, Torsi dan Mementum sudut, Gaya Gesek dan Tekanan, Energi gaya pegas, energi potensial dan gerak lurus, Elastisitas dan beberapa materi fisika lainnya.

Untuk konsep pembelajaran hukum Newton I, II dan III dapat ditemukan pada permainan seperti Gasing, Gatrik, Kelereng dan Tarik Tambang. Untuk konsep pembelajaran keseimbangan dapat ditemukan pada permainan Egrang, Paraga dan Bakiak. Serta ada beberapa konsep pembelajaran fisika yang dapat dijelaskan dalam satu permainan tradisional saja seperti Boi-boian, Bola Bekel, Meriam, Perahu Air, Kasti, Layang-layang dan Bodie.

\section{KESIMPULAN}

Pembelajaran fisika mengintegrasikan etnosains permainan tradisional telah dilakukan peneliti dalam pembelajaran fisika yang sangat erat kaitannya dengan kehidupan nyata sehari-hari, pengintegrasian etnosains dalam pembelajaran fisika sangat penting dilakukan serta memberikan dampak yang signifikan dalam upaya meningkatkan hasil dan motivasi belajar peserta didik serta kearifan lokal dalam bentuk permainan sangat cepat dan familiar pada peserta didik, dengan bermain seperti permainan tradisional membuat peserta didik dengan rasa senang dapat mengikuti dan melakukannya, peserta didik memiliki keterampilan berpikir logis dan kritis dengan melihat peserta didik yang lain saat interaksi dalam bermain.

Penulis menyarankan agar guru dapat mengintegrasikan permainan tradisional dalam pembelajaran fisika. Pada Narrative Literature Review ini didapatkan bahwa ada beberapa konsep pembelajaran fisika seperti Usaha, Perubahan arah gerak benda, Kecepatan yang dapat dijelaskan dalam satu permainan tradisional pada permainan Boi-boian, Bola Bekel, Meriam, Perahu Air, Kasti, Layang-layang dan Bodie. Untuk pengintegrasian dapat diterapkan berupa bahan ajar, modul, elearning dan lain-lainnya.

\section{DAFTAR PUSTAKA}

[1] Kementrian Dalam Negeri, " Rekapitulasi Jumlah PPID Provinsi, Kabupaten dan Kota di Indonesia," vol. 2017, no. 06 Mei, p. 2017, 2017, [Online]. Available: http://www.kemendagri.go.id/media/filemanager/2017/08/23/f/i/file.pdf.

[2] H. Herna, "Kebudayaan Masyarakat Kabupaten Pak Pak Barat," J. Bahas, vol. 26, no. 3, pp. 375-379, 2015.

[3] Misbah and Z. Fuad, "Pengintegrasian Kearifan Lokal Kalimantan Selaan dalam Pembelajaran Fisika," Seminar Nasional Pendidikan Program Studi Pendidikan Fisika FKIP ULM. pp. 294-302, 2019.

[4] L. Novitasari, P. A. Agustina, R. Sukesti, M. F. Nazri, and J. Handhika, "Fisika, Etnosains, dan Kearifan Lokal dalam Pembelajaran Sains," Semin. Nas. Pendidik. Fis. III 2017, pp. 81-88, 2017.

[5] N. P. D. Cahyani, "Permainan Tradisional: Media Pembelajaran di Dalam Kelas BIPA," ASILE Conf., pp. 1-11, 2014.

[6] Sujarno, "Permainan Tradisional Sebagai Jembatan Pembentukan Karakter Bangsa," JANTRA, vol. 6, no. 12, pp. 116-123, 2011.

[7] E. Purwaningsih, "Mengenal Warna, Angka, Huruf Dan Bentuk Pada Anak Usia Dini Melalui Animasi Interaktif," J. Ilmu Pengetah. dan Teknol. Komput., vol. Vol.3 No.2, no. Februari, pp. 203-210, 2018, [Online]. Available: www.bsi.ac.id.

[8] S. Munawaroh, "Permainan Anak Tradisional Sebuah Model Pendidikan Dalam Budaya," 
JANTRA, vol. 6, no. 12, pp. 208-216, 2011.

[9] D. Widyaparamita, Saehana dan I Wayan, "Pengaruh Pembelajaran Fisika dengan Media Permainan Gasing dan Permainan Perahu terhadap Hasil Belajar Siswa SMP Negeri 2 Sigi," vol. 8, no. 2, pp. 45-48, 2020.

[10] N. L. Makhmudah, Subiki, and Supeno, "Pengembangan Modul Fisika Berbasis Kearifan Lokal Permainan Tradisional Kalimantan Tengah Pada Materi Momentum dan Impuls," J. Pembelajaran Fis., vol. 8, pp. 181-186, 2019.

[11] D. A. Santoso and M. A. Setiabudi, "Analisis Matematis Fenomena Fisik Permainan Tarik Tambang," J. Pendidik. Kesehat. Rekreasi, vol. 6, no. 2, pp. 138-145, 2020.

[12] F. Mufit, Asrizal, S. A. Hanum, and A. Fadhilah, "Preliminary research in the development of physics teaching materials that integrate new literacy and disaster literacy," J. Phys. Conf. Ser., vol. 1481, no. 1, 2020, doi: 10.1088/1742-6596/1481/1/012041.

[13] A. Asrizal, F. Festiyed, and R. Sumarmin, "Analisis Kebutuhan Pengembangan Bahan Ajar Ipa Terpadu Bermuatan Literasi Era Digital Untuk Pembelajaran Siswa Smp Kelas Viii,” J. Eksakta Pendidik., vol. 1, no. 1, p. 1, 2017, doi: 10.24036/jep/vol1-iss1/27.

[14] T. Mayasari, "Integrasi budaya Indonesia dengan Pendidikan Sains," Semin. Nas. Pendidik. Fis., no. 2010, pp. 12-17, 2017, [Online]. Available: http://ejournal.unipma.ac.id/index.php/snpf/article/view/1606/1261.

[15] G. Demiris, D. P. Oliver, K. Washington, and K. Pike, “A Problem-Solving Intervention for Hospice Family Caregivers: A Randomized Clinical Trial," J. Am. Geriatr. Soc., pp. 1-8, 2019, doi: 10.1111 /jgs.15894.

[16] Z. Wiyono, K., Ismet, Murniati dan Sri, “Analisis Konsep Dan Prinsip Fisika Pada Permainan Tradisional Dan Ruang Lingkupnya Pada Materi Pembelajaran Fisika Sekolah Menengah Atas," J. Inov. dan Pembelajaran Fis., vol. 4, no. 2, pp. 135-143, 2017, [Online]. Available: ttp://fkip.unsri.ac.id/index.php/menu/104.

[17] M. I. Azizah, "Ilza Ma’azi Azizah,” 2016.

[18] E. S. Noly Shofiyah, Ria Wulandari, "Modul Dinamika Partikel Terintegrasi Permainan Tradisional Berbasis E-Learning untuk Meningkatkan Literasi Sains," vol. 6, no. 2, pp. 292 299, 2020.

[19] Aprilaras Dewi Pertiwi, "Pengembangan Modul Pembelajaran Menggunakan Permainan Tradisional Anak untuk Kelas I SD Tema 3 Subtema 1," Skripsi, vol. 8, no. 5, p. 55, 2019.

[20] F. Agustini, "Integrasi Nilai Karakter Melalui Permainan Tradisional Tarik Tambang Dalam Pembelajaran IPA," J. Ilm. Sekol. Dasar, vol. 4, no. 2, p. 114, 2020, doi: 10.23887/jisd.v4i2.24513.

[21] A. Kusumaningsih and Suryanti, "Efektivitas penerapan permainan tradisional engklek terhadap hasil belajar IPA siswa kelas IV di SDN Lidah Wetan II / 462 Surabaya," Jpgsd, vol. 07, no. 04, pp. 3218-3227, 2019, [Online]. Available: https://jurnalmahasiswa.unesa.ac.id/index.php/jurnal-penelitian-pgsd/article/view/28281.

[22] H. Ashar, "Pengaruh Pembelajaran Diskusi Caologium Berbasis Permainan Engklek Terhadap Hasil Belajar Fisika," J. Pendidik. Fis. UIN Alauddin Makassar, vol. 5, no. 1, pp. 4548, 2017.

[23] Rizalul Fiqry, "Studi Kepustakaan Perancangan Modul Pembelajaran Fisika Berbasis Indiginasi Budaya: Permainan Tradisional Gasing ' Kawongga' Untuk Meningkatkan Keterampilan Berpikir Logis Di Era Pembelajaran Abad 21," Semin. Nas. Fis. dan Apl., pp. 349-356, 2017.

[24] Maulida Rizqi Pratiwi, Pengembangan Media Pembelajaran Fisika Berbasis Permainan Tradisional Untuk. Meningkatkan Penguasaan Materi Dan Kerjasama Peserta Didik SMA, vol. 8, no. 5. 2019.

[25] W. D. B. Muis Tasmil, Khusumadewi Ari, "Development of Blended Learning in Group Dynamics Courses for Guidance and Counseling Students," vol. 03, no. 01, pp. 14-20, 2019. 